\title{
FATTY ACID COMPOSITION OF PHOSPHOLIPIDS AND SORPTION CAPACITY OF HEAD TISSUES AND PRODUCTIVE SIGNS OF BEES FED WITH FLAXSEED OIL
}

\author{
Ivan Saranchuk ${ }^{1}$ \\ Viktoria Vishchur ${ }^{2}$
}

DOI: https://doi.org/10.30525/978-9934-26-050-6-10

Analysis of the available scientific literature indicates that the amount and composition of fatty acids in feed directly and very quickly affects the fatty acid composition and functional activity of cell membranes through phospholipids. In particular, the fatty acid composition of phospholipids of cell membranes is the main factor influencing the intensity of the transition of various compounds, including heavy metals and various forms of fatty acids, by active and passive transportation into the tissues of bees. The egg-laying of queen bees and the honey productivity of worker bees strongly depend on the activity of the latter.

Based on the above, the aim of our research was to establish a link between the content of phospholipids, their fatty acid composition and the sorption capacity of honey bee head tissues and their reproductive capacity and productivity depending on the amount of flaxseed oil in the feed additive.

Experimental studies were conducted in the spring and summer season on clinically healthy honey bees of the Carpathian breed (Apis mellifera

\footnotetext{
${ }^{1}$ Bukovinian State Agricultural Experimental Station

of Institute of Agriculture of Carpathian region of NAAS, Ukraine

${ }^{2}$ Stepan Gzhytskyi National University

of Veterinary Medicine and Biotechnologies Lviv, Ukraine
} 
carpatica). According to the principle of analogues, 3 groups of bee families were formed (3 bee families in each). The bees of the control group received feed additive consisting of $100 \mathrm{~g}$ of low-fat flour from natural soybeans of the Chernivtsi-9 variety and $100 \mathrm{~g}$ of sugar syrup (sugar to water ratio 1:1) for 36 days. In addition to this feed, the bee families of the $1^{\text {st }}$ and $2^{\text {nd }}$ experimental groups received flaxseed oil in the amount of 10 and $20 \mathrm{~g} / \mathrm{bee}$ colony/week, respectively. During the experiment, the egg-laying of queens and worker bees honey productivity were monitored. At the end of the experiment, the sorption capacity, the content of heavy metals, phospholipids and the fatty acid composition in the tissue samples of honey bees were determined.

It was found that due to the addition of flaxseed oil in the amount of 10 and $20 \mathrm{~g}$ into the feed additive which consists of low-fat soy flour and sugar syrup, it demonstrates the dose-dependent increase in the content of saturated, monounsaturated and especially polyunsaturated fatty acids both in fatty acids of total lipids and non-esterified fatty acids. Feeding honey bees with a feed additive enriched with flax oil leads to a dose-dependent increase in the concentration of phospholipids in the tissues of the head of honey bees. At the same time, the relative content of polyunsaturated fatty acids of the $\omega$-3 family increases in the phospholipids of bee tissues of the $1^{\text {st }}$ and $2^{\text {nd }}$ experimental groups, but the content of monounsaturated fatty acids of the $\omega-9$ family decreases. In this case, the ratio of the relative content of polyunsaturated fatty acids of the $\omega-3$ family to the polyunsaturated fatty acids of the $\omega-6$ family in the phospholipids of the head tissues of honey bees of the $1^{\text {st }}$ and $2^{\text {nd }}$ experimental groups grows significantly. The increase in the concentration of phospholipids and the relative content of polyunsaturated fatty acids in the $\omega-3$ family leads to a dose-dependent increase in the sorption capacity of the head tissues of honey bees of the $1^{\text {st }}$ and $2^{\text {nd }}$ experimental groups. At the same time, the tissue of the honey bee head in the $1^{\text {st }}$ and mainly the $2^{\text {nd }}$ experimental groups undergo the increase in the content of Nickel, Plumbum and Cadmium. In addition, the content of Copper and Chromium rises in the tissues of the head of honey bees of the $2^{\text {nd }}$ experimental group. Changes in the content of phospholipids, their fatty acid composition and sorption capacity of the tissues of the head of honey bees of the $1^{\text {st }}$ and especially $2^{\text {nd }}$ experimental groups are accompanied with changes in the reproductive capacity of queens and honey productivity of worker bees. Specifically, the egg laying of queens in the $2^{\text {nd }}$ and, to a greater extent, $1^{\text {st }}$ experimental groups increases by $6.4 \%$ and $15.4 \%$, respectively, and honey productivity of worker bees increases by $10.7 \%$ and $17.5 \%$, respectively. 